\title{
Correlations between silicic volcanic rocks of the St Mary's Islands (southwestern India) and eastern Madagascar: implications for Late Cretaceous India-Madagascar reconstructions
}

\author{
LEONE MELLUSO ${ }^{1 *}$, HETU C. SHETH ${ }^{2}$, JOHN J. MAHONEY ${ }^{3}$, VINCENZO MORRA ${ }^{1}$, \\ CHIARA M. PETRONE ${ }^{4,5} \&$ MICHAEL STOREY ${ }^{6}$ \\ ${ }^{1}$ Dipartimento di Scienze della Terra, Università di Napoli Federico II, 80134 Napoli, Italy \\ ${ }^{2}$ Department of Earth Sciences, Indian Institute of Technology, Powai 400076, Mumbai, India \\ ${ }^{3}$ School of Ocean and Earth Science and Technology, University of Hawaii, Honolulu, HI 96822, USA \\ ${ }^{4}$ Istituto di Geoscienze e Georisorse CNR, University of Firenze, 50121 Firenze, Italy \\ ${ }^{5}$ Present address: Department of Earth Sciences, University of Cambridge, Cambridge CB2 3EQ, UK \\ ${ }^{6}$ QUAD-Lab, Roskilde University Centre, Roskilde, 4000 Denmark \\ *Corresponding author (e-mail: melluso@unina.it)
}

\begin{abstract}
The St Mary's Islands (southwestern India) expose silicic volcanic and sub-volcanic rocks (rhyolites and granophyric dacites) emplaced contemporaneously with the Cretaceous igneous province of Madagascar, roughly 88-90 Ma ago. The St Mary's Islands rocks have phenocrysts of plagioclase, clinopyroxene, orthopyroxene and opaque oxide, moderate enrichment in the incompatible elements (e.g. $\mathrm{Zr}=580-720 \mathrm{ppm}$, $\left.\mathrm{Nb}=43-53 \mathrm{ppm}, \mathrm{La} / \mathrm{Yb}_{\mathrm{n}}=6.9-7.2\right)$, relatively low initial ${ }^{87} \mathrm{Sr} /{ }^{86} \mathrm{Sr}(0.7052-0.7055)$ and near-chondritic initial ${ }^{143} \mathrm{Nd} /{ }^{144} \mathrm{Nd}(0.51248-0.51249)$. They have mineral chemical, whole-rock chemical and isotopic compositions very close to those of rhyolites exposed between Vatomandry-Ilaka and Mananjary in eastern Madagascar, and are distinctly different from rhyolites from other sectors of the Madagascan province. We therefore postulate that the St Mary's and the Vatomandry-Ilaka-Mananjary silicic rock outcrops were adjacent before the Late Cretaceous rifting that split Madagascar from India. If so, they provide a valuable tool to check and aid traditional Cretaceous India-Madagascar reconstructions based on palaeomagnetism, matching Precambrian geological features, and geometric fitting of continental shelves.
\end{abstract}

Supplementary material: Mineral analyses, mass-balance calculations and locality information are available at http://www.geolsoc.org.uk/SUP18332.

Correlation between magmatic units of flood basalt provinces emplaced on conjugate continental margins is a fascinating topic for detailed work. Examples of Phanerozoic provinces where far-separated units have been correlated include the Paraná and Etendeka (Milner et al. 1995; Peate et al. 1999; Marsh et al. 2001), the Karoo province and the FerrarKirkpatrick basalts-Tasmanian dolerites (Hergt et al. 1991; Encarnación et al. 1996; Riley et al. 2006), the Deccan Traps and Seychelles dykes (Devey \& Stephens 1991, 1992), eruptive units in Ethiopia and Yemen (Ukstins Peate et al. 2005), the North Atlantic Tertiary Province (Larsen et al. 1999; Storey et al. 2007) and outcrops of the Central Atlantic Magmatic Province in Europe, the Americas and Africa (Marzoli et al. 1999). Such correlations have been made in some cases by matching distinctive eruptive units, and in other cases by matching stratigraphic packages of compositionally similar lavas, or simply by matching ages of volcanic units. A close chemical match-up of volcanic units can also be made by tephrostratigraphy (Ukstins Peate et al. 2003).

The silicic volcanic and sub-volcanic rocks of the St Mary's Islands, off the SW coast of India (Figs 1 and 2a; Naganna 1966; Hegde \& Gosavi 2007), were thought to be unrelated to the c. $65 \mathrm{Ma}$ Deccan Traps to the north ever since Valsangkar et al. (1981) reported that they had distinctly older $\mathrm{K}-\mathrm{Ar}$ ages
(80-97 Ma). These older ages were later confirmed when Pande et al. (2001) obtained ${ }^{40} \mathrm{Ar}-{ }^{39} \mathrm{Ar}$ plateau and isochron mean ages for St Mary's Islands samples of $85.4 \pm 0.8 \mathrm{Ma}$ $(2 \sigma)$ and $85.6 \pm 0.9 \mathrm{Ma}(2 \sigma)$, respectively (relative to monitor MMhb-1 age of $523.1 \pm 2.6 \mathrm{Ma}, 2 \sigma$; Renne et al. 1998). At about the same time, Torsvik et al. (2000) reported a ${ }^{206} \mathrm{~Pb}-$ ${ }^{238} \mathrm{U}$ zircon age of $91.2 \pm 0.2 \mathrm{Ma}(2 \sigma)$ for a dacite flow. The two sets of ages are notably different relative to analytical errors.

Western India and eastern Madagascar were contiguous until the middle part of the Late Cretaceous (e.g. Katz \& Premoli 1979). It has also long been known that widespread Cretaceous volcanism occurred in Madagascar (Lacroix 1923; Besairie 1964). However, knowledge of this volcanism was poor until the 1990s. There have been many publications since, reporting age data $\left(92-84 \mathrm{Ma},{ }^{40} \mathrm{Ar}-{ }^{39} \mathrm{Ar}\right.$, the ages generally decreasing from north to south) and compositional ranges of the Madagascan rocks (Mahoney et al. 1991, 2008; Storey et al. 1995, 1997; Melluso et al. 1997, 2001, 2002, 2003, 2005; Torsvik et al. 1998). Here, we attempt to place the St Mary's Islands rocks of southwestern India in the context of the Cretaceous volcanism in Madagascar through the use of geochemical and petrological 'fingerprinting', together with plate reconstructions of the relative pre-break-up positions of Madagascar and India. 

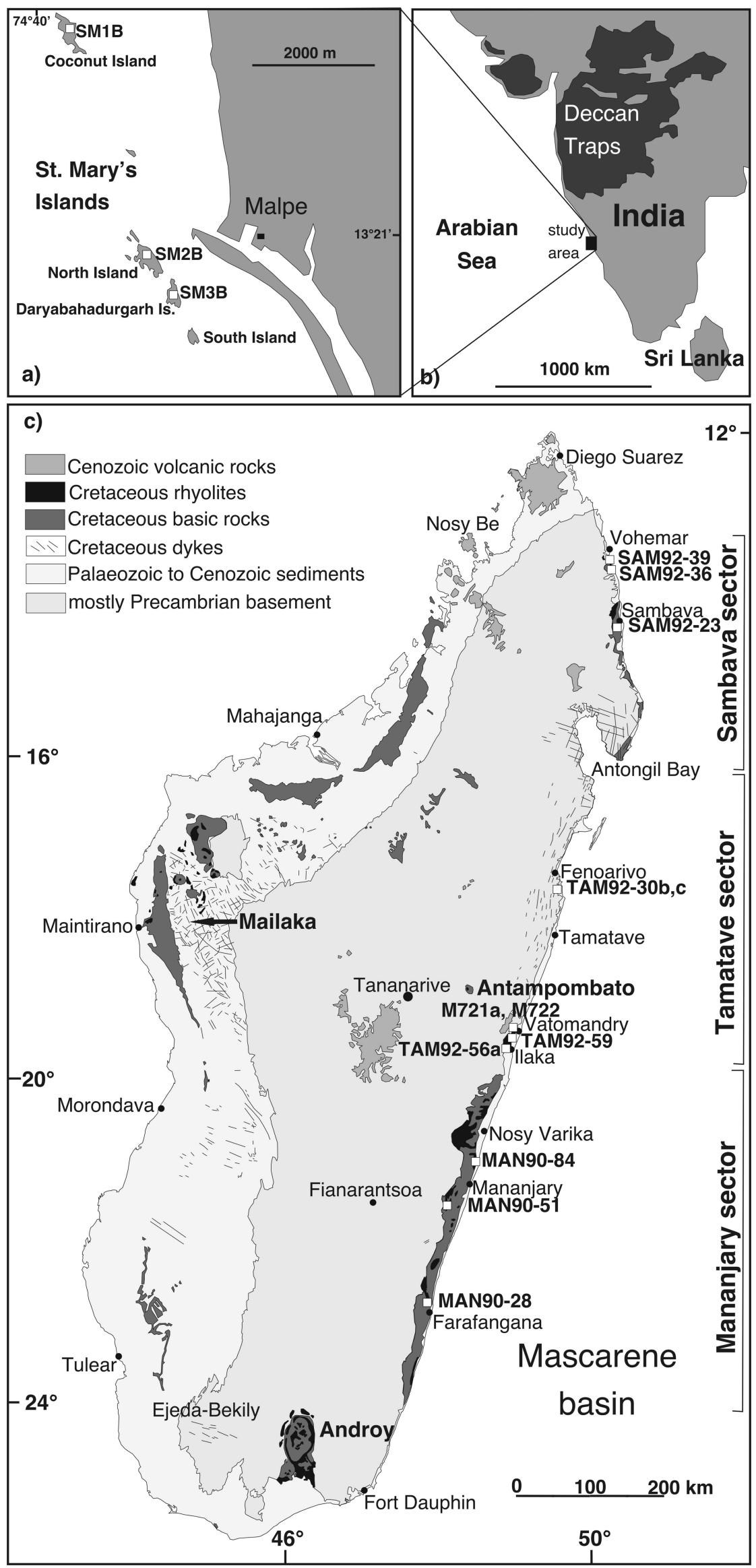

Fig. 1. Sketch maps of the St Mary's Islands (SW India; a, b) and Madagascar (c). The location of the samples reported in Table 1 is also shown. 

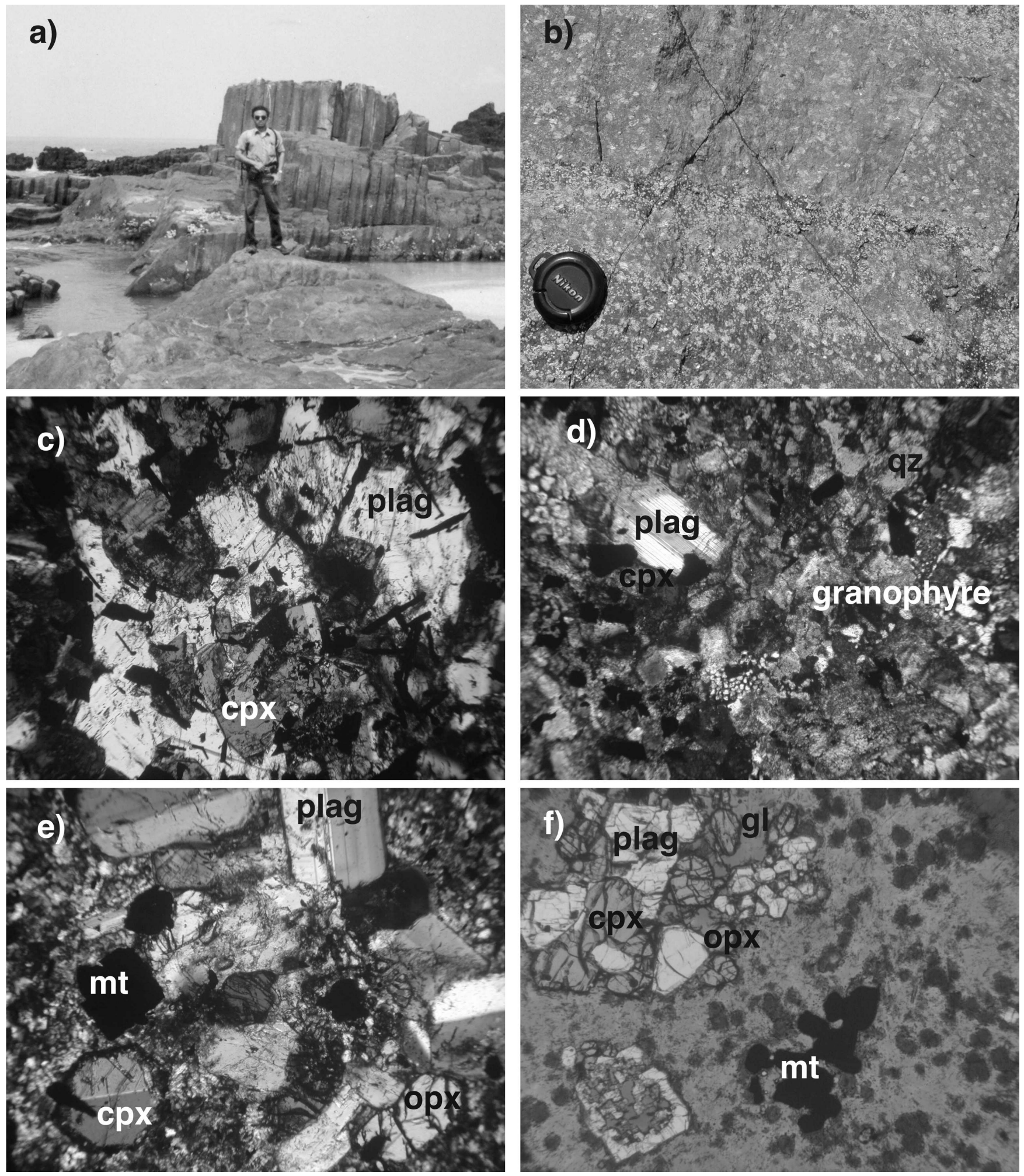

Fig. 2. (a) Columnar jointing in the Coconut Island outcrop, St Mary's Islands (SW India). (b) Outcrop of altered rhyolites between Vatomandry and Ilaka (Madagascar). These rhyolites were emplaced as porphyritic lavas, sometimes with columnar jointing. The complete lack of both flow banding and orientation of the highly altered feldspar phenocrysts should be noted; this feature excludes a former pyroclastic origin of these rocks. (c) Mafic inclusion in SM1B; cross-polarized light (note clinopyroxene and magnetite included in plagioclase). (d) Granophyric intergrowths in sample SM3b; cross-polarized light. (e) Sample SM2B, cluster of orthopyroxene, clinopyroxene, plagioclase and oxides; cross-polarized light. (f) Vitrophyre MAN90-84, Mananjary: cluster of plagioclase, clinopyroxene, orthopyroxene and oxides in a glassy, partially devitrified matrix; plane-polarized light. The long side of each photomicrograph is c. $2 \mathrm{~mm}$. 


\section{Geological setting}

The St Mary's Islands are a group of four small islands (Coconut Island, North Island, Daryabahadurgarh Island and South Island) and several tiny islets, forming a roughly north-south-trending, $6 \mathrm{~km}$ long archipelago, off Malpe, Karnataka state, India (Fig. 1a and $\mathrm{b}$ ). The volcanic rocks of the islands are light to dark grey, and devoid of vesicles. Exposures on Coconut Island show welldeveloped columnar jointing (Fig. 2a), absent on the other islands, but North Island and Daryabahadurgarh Island show outcrops traversed by north-south-striking, steeply dipping joints (Pande et al. 2001). We consider the Coconut Island and North Island outcrops to be lava flows, and not pyroclastic deposits (such as tuffs or ignimbrites), based on outcrop and textural features. The granophyre outcrops on Daryabahadurgarh can be considered shallow-level intrusions, although no contacts are exposed.

The country rock exposed in the Malpe area on the mainland is thick laterite, developed from Precambrian gneiss.

The geological setting of the Madagascar flood basalt province has been described previously (e.g. Besairie 1964; Nicollet 1984; Storey et al. 1995, 1997; Melluso et al. 2005, and references therein). Lavas, dykes, other igneous intrusions and deeply altered pyroclastic rocks cover much of the eastern and western coasts and parts of the hinterland (Fig. 1c). In many areas the lavas lie directly on the Precambrian basement. Silicic rocks have been found throughout the province, although they are a volumetrically minor component (see Besairie 1964; Melluso et al. 2001, 2005; Fig. 1c). Many outcrops of rhyolitic rocks are known along the eastern coast, and rhyolites are abundant in the Androy complex at the southern end of the island (Mahoney et al. 2008) (Fig. 1c). The rhyolitic rocks are mostly dykes and lavas, intruded into or erupted on the coastal Precambrian basement. The rhyolite outcrops from Vatomandry-Ilaka and Mananjary form large, subhorizontal lava fields; among them, outcrops between Vatomandry and Ilaka are roughly $30 \mathrm{~km} \times$ $10 \mathrm{~km}$ and probably 130-140 mt thick (Geological Survey of Madagascar 1959). They are usually found at the top of mafic lava successions, as is often the case in flood basalt provinces (e.g. Peate 1997; Sheth \& Melluso 2008), and in some cases are also intruded by dolerite dykes, although the exact stratigraphic relationships are commonly obliterated by heavy lateritization or hidden by vegetation.

The extent of the Cretaceous volcanic rocks on the continental shelves of Madagascar is largely unknown. From the limited geophysical data available, the eastern part of Madagascar lacks seaward-dipping seismic reflectors, usually believed to be igneous material (e.g. Saunders et al. 1997; Gladczenko et al. 1998), and the continent-ocean transition is very narrow (Storey et al. 1995; Chand \& Subrahmanyam 2003).

\section{Analytical techniques}

Major and trace element contents were determined on agateground powders of the St Mary's Islands rocks and the Madagascan dykes M721a (rhyolite) and M722 (dacite) by inductively coupled plasma optical emission spectrometry and inductively coupled plasma mass spectrometry (ICP-MS) at ACTLABS, Ancaster, Ontario (Table 1). The other chemical analyses of the Madagascan silicic rocks were obtained by X-ray fluorescence spectrometry (XRF) and instrumental neutron activation analysis (INAA), described by Storey et al. (1997). These data are part of a larger XRF dataset for the silicic rocks cropping out along the whole eastern coast of Madagascar (J. J. Mahoney et al., unpubl. data; Fig. 3).

Mineral chemical data were obtained at Istituto di Geologia Ambientale e Geoingegneria, CNR, Rome, utilizing a Cameca SX50 instrument equipped with a wavelength-dispersive spectrometer. Silicates and oxides were used as standards, and the augite Kakanui was used as a monitor of accuracy. A subset of the analyses has been obtained utilizing an energy-dispersive microprobe system linked to a JEOL JSM5310 system operating at 50 $\mathrm{kV}$ and $50 \mu \mathrm{A}$ at CISAG, University of Napoli.

Strontium and $\mathrm{Nd}$ isotope analyses were performed at the Department of Earth Sciences, University of Firenze and at the School of Ocean and Earth Science and Technology, University of Hawaii. At Firenze, around $20 \mathrm{mg}$ of sample powder was dissolved in a $\mathrm{HF}-\mathrm{HNO}_{3}-\mathrm{HCl}$ mixture. Strontium and $\mathrm{Nd}$ fractions were separated following standard chromatographic techniques using AG50x8 and Ln-HDEHP resins with $\mathrm{HCl}$ as eluent, as described by Avanzinelli et al. (2005). Mass spectrometric analyses were performed by thermal ionization mass spectrometry on a Thermo Finnigan Triton- $\mathrm{Ti}^{\circledR}$ system equipped with nine movable Faraday cups. The ${ }^{87} \mathrm{Sr} /{ }^{86} \mathrm{Sr}$ and ${ }^{143} \mathrm{Nd} /{ }^{144} \mathrm{Nd}$ ratios were measured dynamically in a triple jump routine, except for ${ }^{143} \mathrm{Nd} /{ }^{144} \mathrm{Nd}$ of samples M721 and M722, which was measured in static mode. Sample preparation and analysis at Hawaii followed Mahoney et al. (1991) and employed a VG Sector multicollector mass spectrometer for the measurements.

\section{Petrography, mineral chemistry and whole-rock geochemistry of St Mary's Islands rocks}

The St Mary's Islands rocks are porphyritic rhyolites (SM1B, Coconut Island; SM2B, North Island) and dacites (sample SM3B, Daryabahadurgarh Island). Samples SM1B and SM2B have been dated by Pande et al. (2001) using the ${ }^{40} \mathrm{Ar}-{ }^{39} \mathrm{Ar}$ incremental heating method. The rocks are quartz normative $(23.8-27.5 \%)$ and are not peraluminous, as shown by the ubiquitous presence of clinopyroxene. In the total alkali-silica (TAS) diagram, the analyses plot in the same general space as data for the rhyolites, dacites and trachytes of eastern Madagascar (Fig. 3). The dominant phenocrysts in the St Mary's rocks are zoned plagioclase and lesser amounts of clinopyroxene, orthopyroxene, magnetite and ilmenite (Fig. $2 \mathrm{~d}$ and e). The groundmass is fine-grained (sample SM1B) or granophyric (sample SM2B and, particularly, granophyre SM3B) and consists of the same minerals, as well as alkali feldspar and quartz. Biotite has been found as a rim on magnetite. Apatite and zircon are accessory phases. Clusters of gabbroic or doleritic appearance ("mafic inclusions') occur in the Coconut Island rhyolite (Fig. 2c). They are made up of intergrowths of plagioclase, clinopyroxene and oxides, and could represent mingled magma batches or fragments of basaltic rock incorporated at depth.

Plagioclase ranges in composition from $\mathrm{An}_{56}$, found in the core of a crystal in a mafic inclusion, to $\mathrm{An}_{16}$ in the rim of a phenocryst of sample SM1B. Secondary albite rims have been found, as was Na-rich alkali feldspar $\left(\mathrm{Or}_{20} \mathrm{Ab}_{76}\right)$. Augite $\left(\mathrm{Ca}_{38-40} \mathrm{Mg}_{41-43} \mathrm{Fe}_{18-20}\right.$; $\mathrm{Mg}$-number $=0.68-0.70, \quad$ where $\mathrm{Mg}$-number $=$ atomic $\quad \mathrm{Mg} /$ $(\mathrm{Mg}+\mathrm{Fe}))$, and orthopyroxene $\left(\mathrm{Ca}_{3} \mathrm{Mg}_{60-62} \mathrm{Fe}_{35-37} ; \mathrm{Mg}\right.$-number $=0.62-0.64)$ are the two pyroxenes of the St Mary's Islands rocks (Fig. 4a). The $\mathrm{TiO}_{2}$ concentration in the augite phenocrysts is relatively low (0.4-0.9 wt\%). Equilibration temperatures based on two-pyroxene geothermometry (Lindsley 1983) are around $1000^{\circ} \mathrm{C}$. The mafic inclusion has more calcic plagioclase $\left(\mathrm{An}_{56-41}\right)$ than the phenocrysts of the lavas $\left(\mathrm{An}_{41-35}\right)$. The augites of the mafic inclusion $\left(\mathrm{Ca}_{38-41} \mathrm{Mg}_{39-45} \mathrm{Fe}_{17-19}\right)$ have slightly more 


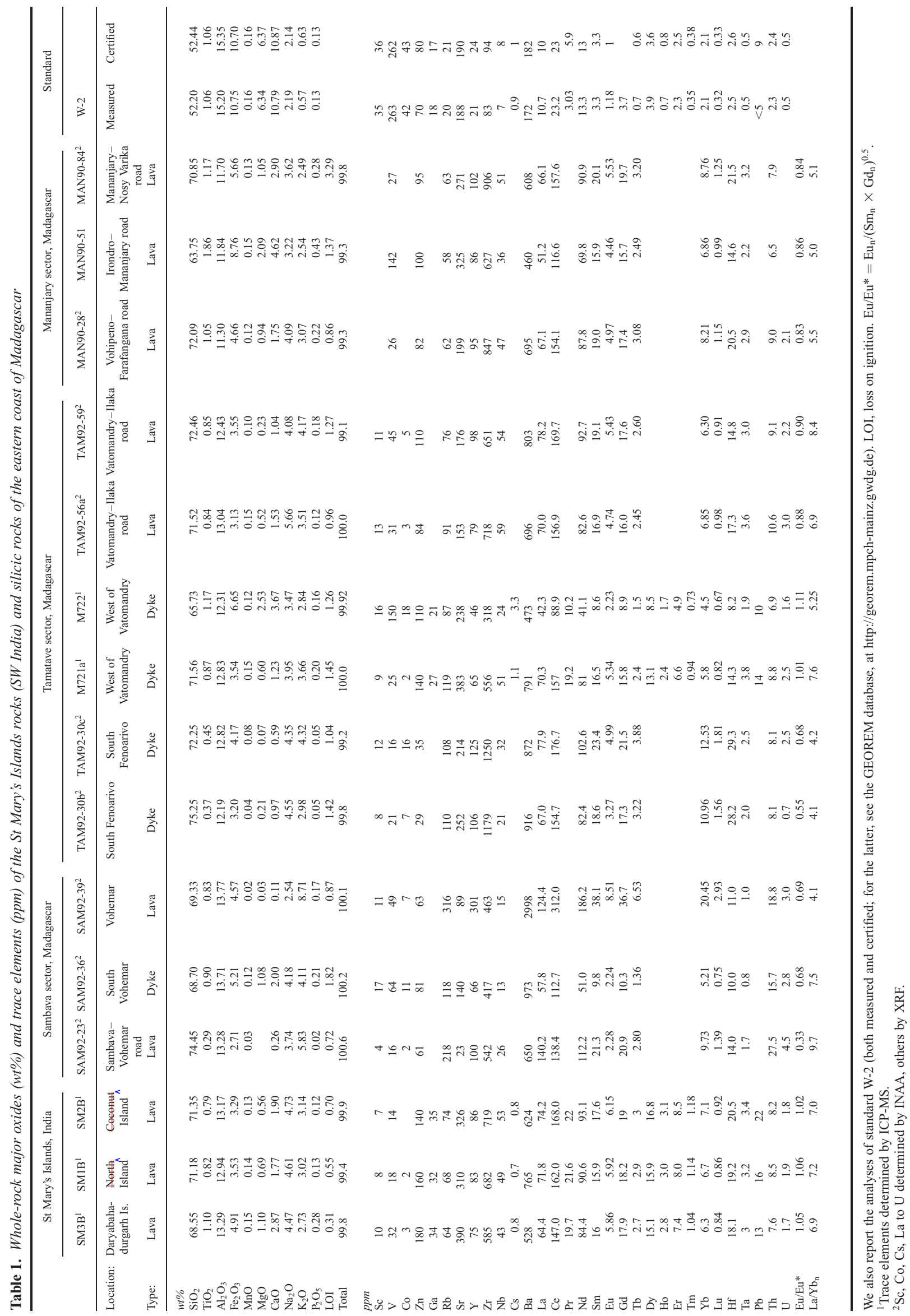



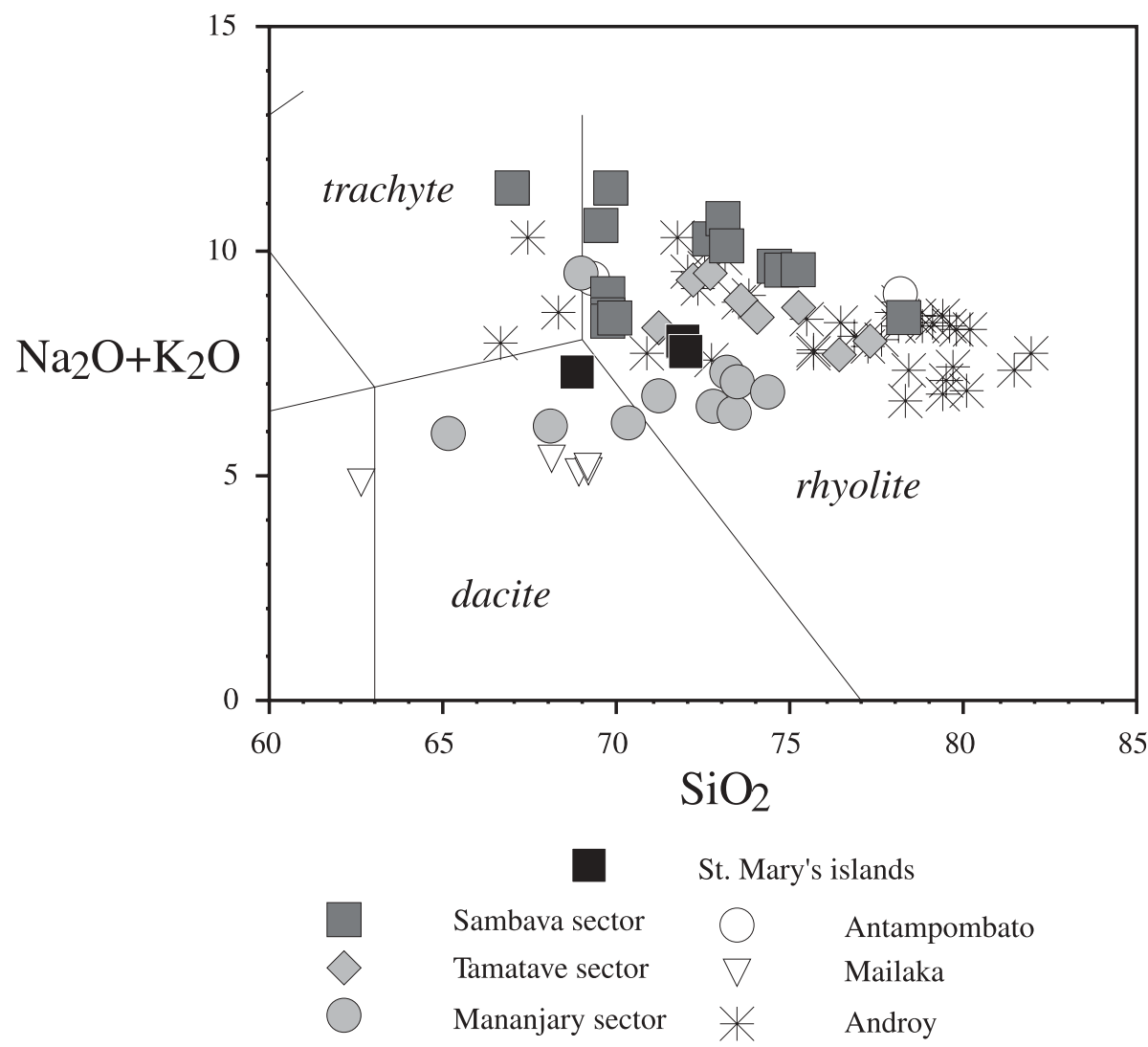

Fig. 3. Classification of the samples using the total alkali-silica (TAS) diagram of Le Bas et al. (1986). The St Mary's Islands samples (India) are shown as filled squares. The other data are for Madagascar silicic rocks, taken from Melluso et al. (2001, 2005), Mahoney et al. (2008) and J. J. Mahoney et al. (unpubl. data). variable $\mathrm{Mg}$-number $(0.67-0.73)$ than the values found in the phenocrysts of the lavas, and have also slightly higher $\mathrm{TiO}_{2}(0.9-$ $2.2 \mathrm{wt} \%$ ). Ti-magnetite and ilmenite have been found coexisting. Their very narrow ranges of calculated equilibration temperatures and oxygen fugacities are $733-756^{\circ} \mathrm{C}$ and $10^{-13.2}-10^{-12.4}$ bars $f \mathrm{O}_{2}$, respectively (using Lepage 2003, and references therein), suggesting subsolidus re-equilibration. The data plot above the nickel-nickel oxide (NNO) synthetic buffer, indicating a more oxidized environment than inferred from the range of values for northern Madagascan rocks, which cluster around the quartzfayalite-magnetite (QFM) synthetic buffer (Melluso et al. 2001, 2005, 2006). Biotite rimming magnetite has high $\mathrm{Mg}$-number (0.70). It is moderately Ti-rich $\left(\mathrm{TiO}_{2} 3.4 \mathrm{wt} \%\right)$. Overall, the range of these mineral compositions is similar to that found by Valsangkar (1980) and Subbarao et al. (1993) for the St Mary's Islands rocks.

The St Mary's Islands rhyolites and dacites have low contents of $\mathrm{CaO}(1.9-2.9 \mathrm{wt} \%), \mathrm{MgO}(0.6-1.1 \mathrm{wt} \%)$, total iron as $\mathrm{Fe}_{2} \mathrm{O}_{3}$ (3.3-4.9 wt \%), $\mathrm{TiO}_{2}(0.8-1.1 \mathrm{wt} \%)$ and $\mathrm{P}_{2} \mathrm{O}_{5}(0.12-0.28 \mathrm{wt} \%)$, and relatively high $\mathrm{Na}_{2} \mathrm{O}(4.4-4.7 \mathrm{wt} \%)$ and $\mathrm{K}_{2} \mathrm{O}(2.7-3.1 \mathrm{wt} \%)$, indicating a moderate degree of chemical variation. The rocks are characterized by relatively high concentrations of incompatible elements such as $\mathrm{Zr}(585-719 \mathrm{ppm}), \mathrm{Nb}$ (43-53 ppm), Y (75-86 ppm), Ba (528-624 ppm) and $\mathrm{Rb}(64-74 \mathrm{ppm})$, increasing with decreasing $\mathrm{MgO}$. Vanadium, $\mathrm{Sc}, \mathrm{Zn}$ and $\mathrm{Sr}$ concentrations decrease with $\mathrm{MgO}$ (Table 1). The increase in $\mathrm{Zr}$ with decreasing $\mathrm{MgO}$ precludes significant fractionation of zircon.

The St Mary's Islands rocks have moderately high ratios of light REE (LREE) to heavy REE (HREE) (e.g. La/Yb $\mathrm{Yb}_{\mathrm{n}}=6.9-7.2$; the subscript $\mathrm{n}$ means chondrite normalized; chondrite values of Boynton 1984), and lack negative Eu anomalies $\left(\mathrm{Eu} / \mathrm{Eu}^{*}=1.02-\right.$ 1.06 , where $\mathrm{Eu}$ is the normalized measured value and $\mathrm{Eu}^{*}$ is interpolated $\mathrm{Eu}$ between normalized $\mathrm{Gd}$ and $\mathrm{Sm}$ ), a remarkable feature for dacites and rhyolites (Table 1). Moderately high $\mathrm{La} / \mathrm{Nb}$ (1.4-1.5) and $\mathrm{Ba} / \mathrm{Nb}(11.8-15.6)$ ratios are observed.

Initial (at $88 \mathrm{Ma}$ ) ${ }^{87} \mathrm{Sr} /{ }^{86} \mathrm{Sr}$ and ${ }^{143} \mathrm{Nd} /{ }^{144} \mathrm{Nd}$ range from 0.70539 to 0.70571 and from 0.512481 to 0.512488 , respectively (Table 2); $\varepsilon_{\mathrm{Nd}}(88 \mathrm{Ma})$ ranges from -0.8 to -0.9 epsilon units. This small range of variation does not permit significant variable open-system processes within the dacite-rhyolite compositional range. The values plot close to the limit of the $\mathrm{Sr}-\mathrm{Nd}$ isotopic range of basalts of northern and eastern Madagascar $\left({ }^{87} \mathrm{Sr} /{ }^{86} \mathrm{Sr}\right.$ $0.70295-0.70681 ; \varepsilon_{\mathrm{Nd}}+7.4$ to -5.3 ) (Fig. 5).

The major and trace element variations within the St Mary's Islands rocks are compatible with $11 \%$ crystal fractionation of a dioritic composition, starting from sample SM3B, to obtain $\mathrm{SM} 2 \mathrm{~B}$. The relatively high concentrations of elements such as $\mathrm{Zr}, \mathrm{Nb}, \mathrm{Y}$ and $\mathrm{Ba}$, the lack of negative $\mathrm{Eu}$ anomalies, the relatively low $\mathrm{La} / \mathrm{Nb}$ and $\mathrm{Ba} / \mathrm{Nb}$, and the relatively low initial ${ }^{87} \mathrm{Sr} /{ }^{86} \mathrm{Sr}$ and high ${ }^{143} \mathrm{Nd} /{ }^{144} \mathrm{Nd}$, with $\varepsilon_{\mathrm{Nd}}$ values close to the chondritic average value, indicate that the St Mary's Islands rocks are unlikely to be a product of anatexis of typical Precambrian upper or lower continental crust. They may be anatectic melts of previously intruded Cretaceous basalts or, more likely, the result of prolonged crystal fractionation and some crustal contamination of a tholeiitic basalt parental magma.

\section{The eastern Madagascar rhyolites: searching for equivalents of the St Mary's Islands silicic rocks}

It is worth noting that evolved rock located away from the eastern Madagascar coast, such as the western Madagascar (Mailaka), Antampombato and Androy dacites, trachydacites and rhyolites, have very strong petrographic differences from the St Mary's Islands rocks, which exclude any common petrogenetic evolution. For example, the Mailaka dacites are peraluminous, 

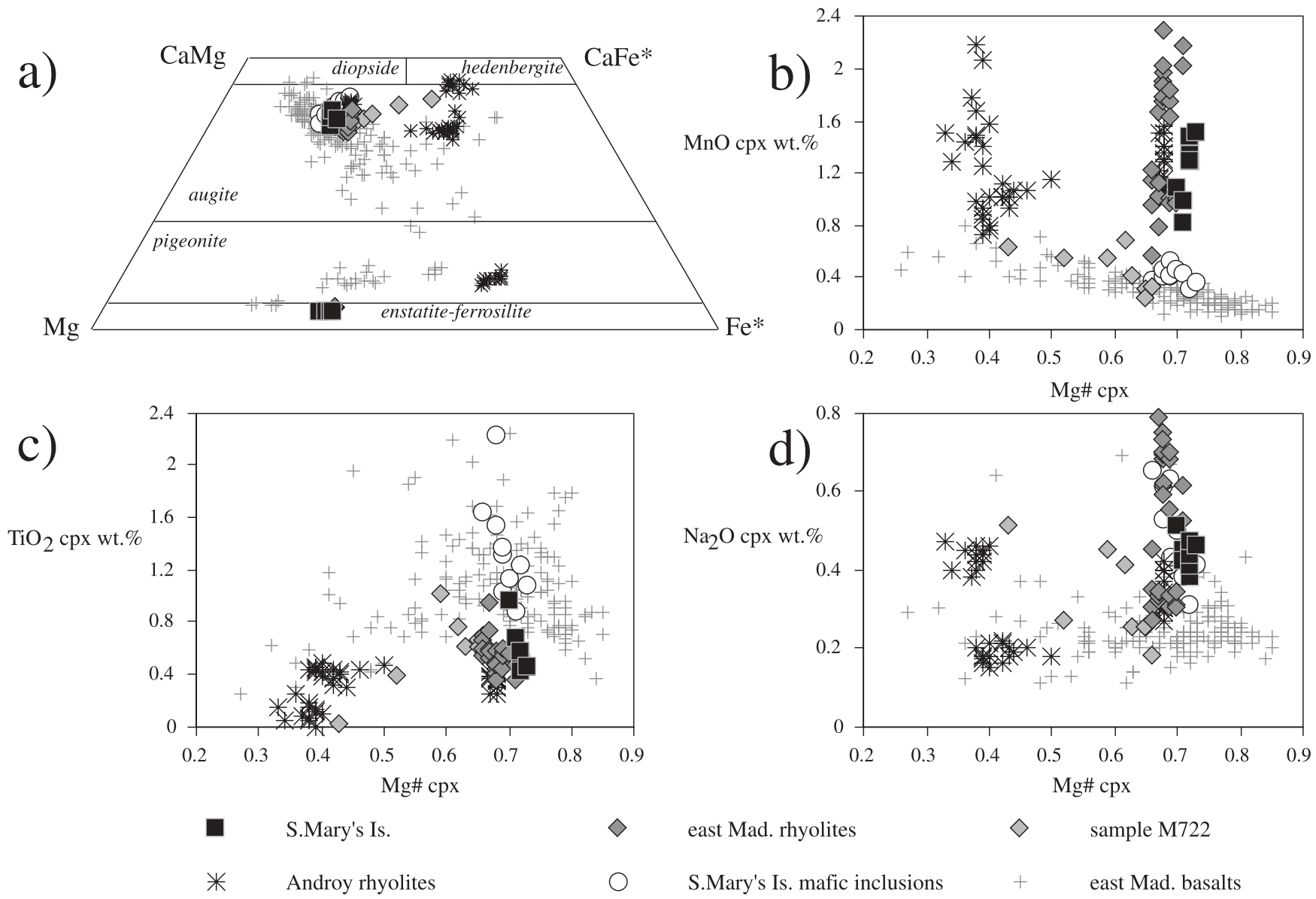

east Mad. rhyolites

$\diamond \quad$ sample M722

S.Mary's Is. mafic inclusions $\quad+\quad$ east Mad. basalts

Fig. 4. (a) Pyroxene diagram (Ca, Mg, Fe $+\mathrm{Mn}$ in mol\%) of St Mary's Islands rocks (black squares), St Mary's Islands mafic inclusions (circles) and Mananjary-Vatomandry-Ilaka rhyolites (dark grey diamonds) The pyroxene of the dacite M722 is shown as light grey diamonds. The composition of pyroxene in the eastern Madagascar and Androy basalts (grey crosses; data from Melluso et al. 2002, 2006, unpubl. data; Mahoney et al. 2008) and in the Androy rhyolites (asterisks) is also shown. The similarity between the chemical composition of the St Mary's Islands augite phenocrysts and those found in eastern Madagascar rhyolites (and those of the high-silica rhyolite AND90-83 of the Androy volcanic complex; see Mahoney et al. 2008) is noteworthy. (b-d) Chemical composition of St Mary's islands augites (both phenocrysts and mafic inclusions) compared with that of augites and ferroaugites of Mananjary-Vatomandry, Androy rhyolites and the associated basalts (dykes or lava flows). Data are from the present paper, Mahoney et al. (2008) and Melluso et al. (2006), references therein, and L. Melluso (unpubl. data).

and contain cordierite phenocrysts rather than clinopyroxene (Melluso et al. 2001). The few Antampombato rhyolites (Melluso et al. 2005) and some of the uppermost Androy rhyolites are peralkaline, and carry minerals such as ferrosalitic (hedenbergitic) clinopyroxene and sodic amphibole (Mahoney et al. 2008), minerals barely seen in evolved rocks of typical tholeiitic affinity. These rocks have other chemical and isotopic differences with the St Mary's Islands rocks, not to mention their relatively large geographical distances from the east coast of Madagascar.

The search for equivalents of the St Mary's Islands rocks in Madagascar should therefore be made along or close to its eastern coast. We distinguish the eastern Madagascar silicic rocks on a geographical basis, following the distinction made by Storey et al. (1997) on the mafic flows and dykes: Sambava (north), Tamatave (centre) and Mananjary (centre-south) (Fig. 1; Table 1).

Some rhyolites and trachytes of eastern Madagascar appear very weakly peralkaline (agpaitic index (AI), i.e. molar $(\mathrm{Na}+$ $\mathrm{K}) / \mathrm{Al}$, up to 1.05). Considering the systematic presence of plagioclase, the absence of sodic pyroxene or amphibole, and the degree of alteration of the samples, no rhyolites from Tamatave or Mananjary can be considered true peralkaline rocks.

From among the eastern Madagascan silicic rocks, samples
MAN90-84, MAN90-28, M722 and TAM92-56a (Table 1) come from the Mananjary and Vatomandry sectors (Fig. 1a). These samples are porphyritic, and some are pitchstones (Fig. 2f). The samples are generally very altered (particularly those cropping out in the Vatomandry-Ilaka area), although a few are relatively fresh. Plagioclase is the main phenocryst phase, and is accompanied by smaller amounts of augite, orthopyroxene, magnetite and ilmenite. Devitrification is widespread, even though relatively fresh glass is sometimes observed (sample MAN90-84 from near Mananjary). Plagioclase phenocrysts in MAN90-84 range from $\mathrm{An}_{49}$ to $\mathrm{An}_{44}$. Augite $\left(\mathrm{Ca}_{36-38} \mathrm{Mg}_{40-43} \mathrm{Fe}_{20-23} ; \mathrm{Mg}\right.$ number $=0.64-0.68)$ and orthopyroxene $\left(\mathrm{Ca}_{4} \mathrm{Mg}_{59} \mathrm{Fe}_{37} ; \mathrm{Mg}\right.$ number $=0.61-0.62)$ are the two pyroxenes of the Mananjary and Tamatave rhyolites (Fig. 4a). Coexisting Ti-magnetite and ilmenite have calculated equilibration temperatures of $912^{\circ} \mathrm{C}$ and oxygen fugacity of $10^{-10.6}$ bars, again plotting above the NNO synthetic buffer, but displaced to higher temperatures than those of St Mary's Islands rocks. Two-pyroxene geothermometry (Lindsley 1983) yields values close to $1000{ }^{\circ} \mathrm{C}$, almost identical to those of the St Mary's Islands rocks. The M722 rhyolite (west of Vatomandry) has sodic plagioclase $\left(\mathrm{An}_{36-29}\right)$ strongly albitized near the rims, alkali feldspar, and clinopyroxene with a larger 
Table 2. Strontium-neodymium isotopic data for the St. Mary's Islands rocks

\begin{tabular}{|c|c|c|c|c|c|c|c|}
\hline & \multicolumn{3}{|c|}{ St Mary's Islands } & \multicolumn{2}{|c|}{ Vatomandry } & \multicolumn{2}{|c|}{ Mananjary } \\
\hline & SM3B & SM1B & SM2B & M721a & M722 & MAN90-28 & MAN90-84 \\
\hline $\mathrm{Sr}$ & 390 & 310 & 326 & 383 & 238 & 238.5 & 279.7 \\
\hline $\mathrm{Nd}$ & 84.4 & 90.6 & 93.1 & 81 & 41.1 & 71.50 & 86.28 \\
\hline $\mathrm{Sm}$ & 16 & 15.9 & 17.6 & 16.5 & 8.6 & 14.37 & 19.89 \\
\hline${ }^{87} \mathrm{Sr} /{ }^{86} \mathrm{Sr}$ measured & 0.70582 & 0.70629 & 0.70608 & 0.70916 & 0.70650 & 0.70614 & 0.70470 \\
\hline${ }^{143} \mathrm{Nd} /{ }^{144} \mathrm{Nd}$ measured & 0.512547 & 0.512547 & 0.512554 & 0.512470 & 0.512314 & 0.512640 & 0.512742 \\
\hline Error $( \pm)$ & 0.000005 & 0.000005 & 0.000004 & 0.000006 & 0.000006 & & \\
\hline${ }^{143} \mathrm{Nd} /{ }^{144} \mathrm{Nd}(88 \mathrm{Ma})$ & 0.512481 & 0.512486 & 0.512488 & 0.512399 & 0.512241 & 0.512570 & 0.512662 \\
\hline$\varepsilon_{\mathrm{Nd}}(88 \mathrm{Ma})$ & -0.9 & -0.8 & -0.8 & -2.5 & -5.6 & 0.8 & 2.6 \\
\hline
\end{tabular}

The element concentrations shown here are from Table 1. Sr, Nd and Sm of MAN samples have been analysed using isotope dilution. For the analyses performed at Firenze, uncertainties in measured isotopic ratios refer to the least significant digits; they are reported as 2 standard errors for within-run precision and 2 standard deviations for external precision on standards. The ${ }^{87} \mathrm{Sr} /{ }^{86} \mathrm{Sr}$ value for the NBS987 standard measured during the course of this work was $0.710247 \pm 11(n=10)$. The ${ }^{143} \mathrm{Nd} /{ }^{144} \mathrm{Nd}$ value for the La Jolla standard was $0.511846 \pm 6(n=7)$. The total procedural blank was $211 \mathrm{pg}$ for $\mathrm{Sr}$ and $<100 \mathrm{pg}$ for Nd, making blank correction negligible. Samples MAN90-28 and MAN90-84 were measured at the University of Hawaii. These data are reported relative to measured ${ }^{87} \mathrm{Sr} /{ }^{86} \mathrm{Sr}=0.710238 \pm 0.000014(2 \sigma, n=29)$ for NBS987 $\mathrm{Sr}$ and to ${ }^{143} \mathrm{Nd} /{ }^{144} \mathrm{Nd}=0.511843 \pm 0.000008\left(2 \sigma, n=28\right.$; this uncertainty corresponds to $\pm 0.2 \varepsilon_{\mathrm{Nd}}$ units $)$ for La Jolla Nd. Within-run uncertainties on the isotope ratios for the samples are less than these external uncertainties. Blanks are negligible at $<60 \mathrm{pg}$ for $\mathrm{Sr}$ and $<10 \mathrm{pg}$ for Nd. Exponential-law fractionation corrections in both laboratories use ${ }^{86} \mathrm{Sr} /$ ${ }^{88} \mathrm{Sr}=0.1194$; in Hawaii, the correction for $\mathrm{Nd}$ uses ${ }^{148} \mathrm{NdO} /{ }^{144} \mathrm{NdO}=0.242436$; in Firenze, ${ }^{146} \mathrm{Nd} /{ }^{144} \mathrm{Nd}=0.1719$ is used. Present-day $\varepsilon_{\mathrm{Nd}}=0$ corresponds to ${ }^{143} \mathrm{Nd} /$ ${ }^{144} \mathrm{Nd}=0.512640$

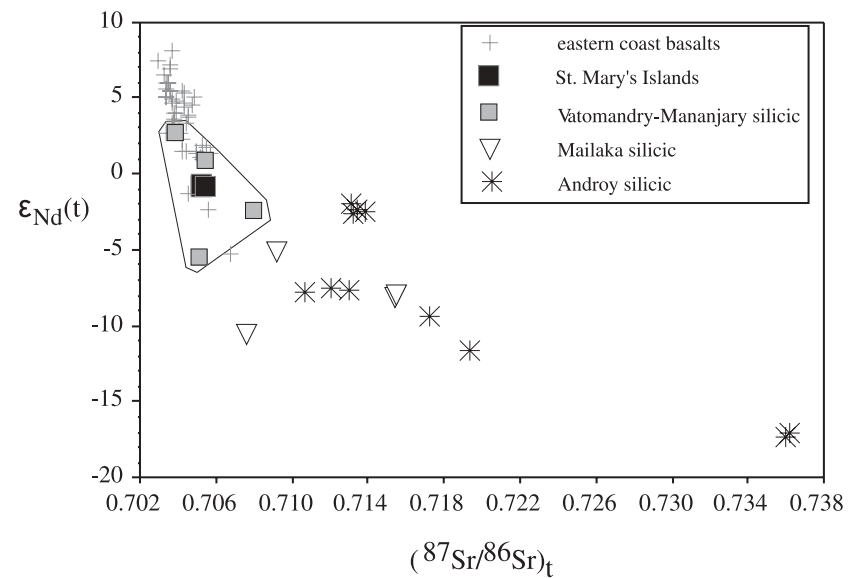

Fig. 5. Initial (at $88 \mathrm{Ma}){ }^{87} \mathrm{Sr} /{ }^{86} \mathrm{Sr}-\varepsilon_{\mathrm{Nd}}$ isotope diagram for the St Mary's Islands rocks (black squares) and eastern Madagascar rhyolites. The data for other silicic rocks and basalts of eastern Madagascar are from Mahoney et al. (1991, 2008), Storey et al. (1997) and Melluso et al. (2001, 2002, 2003, 2005).

and clearly different range of compositions with respect to the other rhyolites $\left(\mathrm{Ca}_{42-38} \mathrm{Mg}_{40-24} \mathrm{Fe}_{21-33} ; \mathrm{MnO}\right.$ from 0.23 to $0.67 \mathrm{wt} \%$ ) (see Fig. $4 \mathrm{a}-\mathrm{c}$ ).

REE patterns of the eastern Madagascar rhyolites show moderate fractionation between LREE and HREE. For example, $\mathrm{La} / \mathrm{Yb}_{\mathrm{n}}=4.1-9.7$ for the Sambava samples, $\mathrm{La} / \mathrm{Yb}_{\mathrm{n}}=4.1-8.4$ for the Tamatave samples and $\mathrm{La} / \mathrm{Yb}_{\mathrm{n}}=5.1-5.5$ for Mananjary samples. Some of the samples have negative $\mathrm{Eu}$ anomalies, whereas others do not $\left(\mathrm{Eu} / \mathrm{Eu}^{*}=0.33-1.1\right)$.

A few rhyolites in eastern Madagascar have incompatible element patterns that are very similar, in both elemental abundances and ratios, to those of the St Mary's Islands rocks. In particular, lavas and dykes of the Vatomandry-Ilaka area in the Tamatave sector (M721a, TAM92-56a and TAM92-59) provide a good match in REE and more comprehensive incompatible element patterns (Fig. 6) and ratios (e.g. La/ $\mathrm{Yb}_{\mathrm{n}} 6.8-8.4$ v. 6.97.2; $\mathrm{Eu} / \mathrm{Eu}^{*} 0.88-1.01$ v. 1.02-1.06). Rhyolites MAN90-84 and
MAN90-28, and dacite MAN90-51 have patterns matching those of the St Mary's Islands samples (Fig. 6). In contrast, rhyolites and trachytes of the Sambava area are chemically distinct, in that they have generally higher contents of elements such as $\mathrm{Rb}, \mathrm{Ba}$, Th and light lanthanides, and more marked troughs at Sr, P, Eu and Ti (Fig. 6).

Initial ${ }^{87} \mathrm{Sr} /{ }^{86} \mathrm{Sr}$ and ${ }^{143} \mathrm{Nd} /{ }^{144} \mathrm{Nd}$ of Mananjary rhyolites MAN90-28 and MAN90-84 (Fig. 1), are 0.70522, and 0.70390 and 0.512570 and $0.512662\left(\varepsilon_{\mathrm{Nd}(88)}=+0.8\right.$ to +2.6$)$, respectively. Initial ${ }^{87} \mathrm{Sr} /{ }^{86} \mathrm{Sr}$ and ${ }^{143} \mathrm{Nd} /{ }^{144} \mathrm{Nd}$ of Vatomandry rhyolite and dacite dykes (M721a, M722) range from 0.70552 to 0.70833 and from 0.512399 to $0.512241\left(\varepsilon_{\mathrm{Nd}(88)}=-2.5\right.$ to -5.6$)$, respectively (Table 2). The data are within the observed ranges of the associated basalts of the eastern coast and plot far from the fields of other silicic rocks of the province, particularly the Mailaka dacites (Melluso et al. 2001) and the Androy dacites, trachydacites and rhyolites (Mahoney et al. 2008; Fig. 5).

Data for the clinopyroxenes of the St Mary's Islands dacites and rhyolites and of many rhyolites of the eastern coast of Madagascar plot in the same fields, not only on plots of major elements with a narrow range of variation (such as $\mathrm{Ca}, \mathrm{Mg}$, and Fe) (Fig. 4a), but also for $\mathrm{MnO}$ (up to $2.3 \mathrm{wt} \%$ ) and $\mathrm{Na}_{2} \mathrm{O}$ (up to $0.75 \mathrm{wt} \%$ ) and low $\mathrm{TiO}_{2}$ and $\mathrm{Al}_{2} \mathrm{O}_{3}$ at $\mathrm{Mg}$-number $=0.70-$ 0.64 (Fig. 4b). The augites are clearly distinct from those of the associated tholeiitic basalts (Fig. 4b) and are different also from pyroxenes of other rhyolites, such as those found in sample M722. On the other hand, the clinopyroxenes of the mafic inclusions of St Mary's Islands plot within the range of the associated basalt dykes of the eastern coast and the Androy (Fig. $4 \mathrm{a}-\mathrm{c}$ ). In addition, orthopyroxenes of both St Mary's Islands and eastern Madagascar rhyolites have unusually high $\mathrm{MnO}$ content for their Mg-number (1.7-3.2 wt\% at Mg-number $=0.64-0.61)$.

Regardless of the causes of the different minor element composition of clinopyroxene of basalts and rhyolites, there is compelling evidence that the clinopyroxenes of the rhyolites are not inherited phases from the basalts and we believe that their composition is a highly distinctive petrogenetic feature. Thus, similar petrogenetic evolution and extremely similar physicochemical conditions are suggested from clinopyroxene chemical 


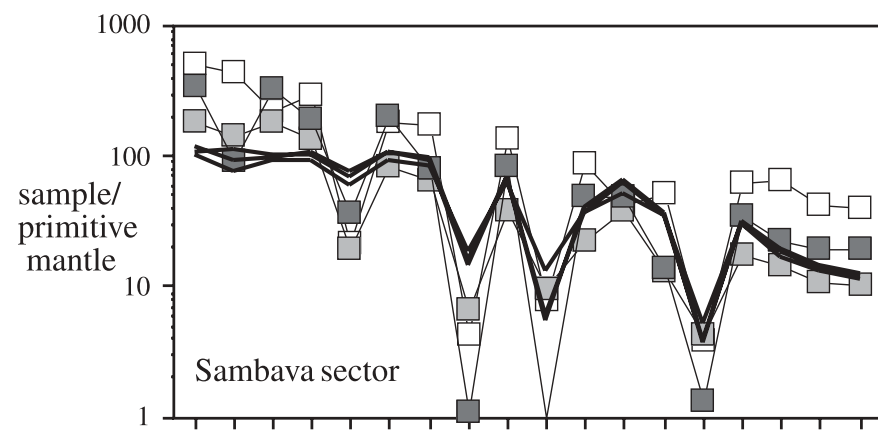

$\mathrm{Rb} \mathrm{BaTh}$ K Nb La Ce Sr Nd P Sm Zr Eu Ti Gd Y Yb Lu

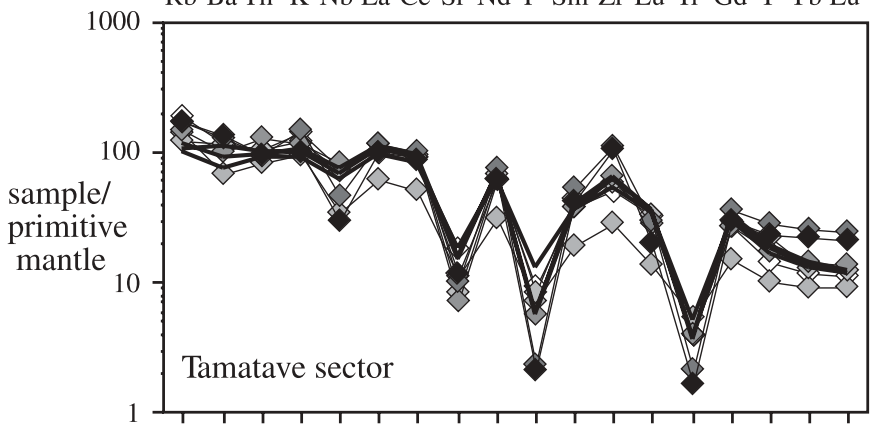

$\mathrm{Rb} \mathrm{BaTh}$ K Nb La Ce Sr Nd P Sm Zr Eu Ti Gd Y Yb Lu

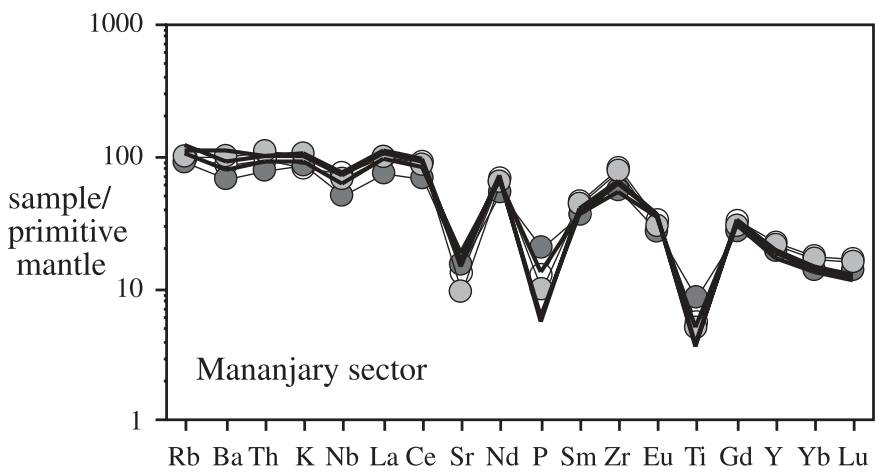

compositions of many silicic magmas of central-western Madagascar and southwestern India.

Regarding $\mathrm{Sr}-\mathrm{Nd}$ isotope ratios, the St Mary's Islands silicic rocks have slightly more radiogenic $\mathrm{Sr}$ and less radiogenic $\mathrm{Nd}$ isotope ratios than most eastern Madagascan basalts (Storey et al. 1997; Melluso et al. 2002, 2005), but they fall well within the compositional range we have found in the eastern Madagascar (Mananjary-Vatomandry) rhyolites, close to the isotopic composition of sample MAN90-28 (Fig. 5).

Considering all observations, the St Mary's Islands rocks, although having slightly different petrographic characteristics from the Vatomandry-Ilaka and Mananjary rhyolites, are closely similar in mineral compositions and whole-rock geochemical and isotopic compositions. These similarities cannot be fortuitous, given the differences in these aspects between the St Mary's Islands rocks and rhyolites elsewhere in eastern and southern Madagascar. Thus, there is possibility of correlation between the St Mary's islands rocks and the Vatomandry-Ilaka-Mananjary silicic rocks along the central-southern strip of the Madagascan east coast.

\section{Palaeogeographical implications}

Having established that the St Mary's Islands dacites and rhyolites have geochemical equivalents in silicic lavas and dykes cropping out along the central-southern stretch of the east coast
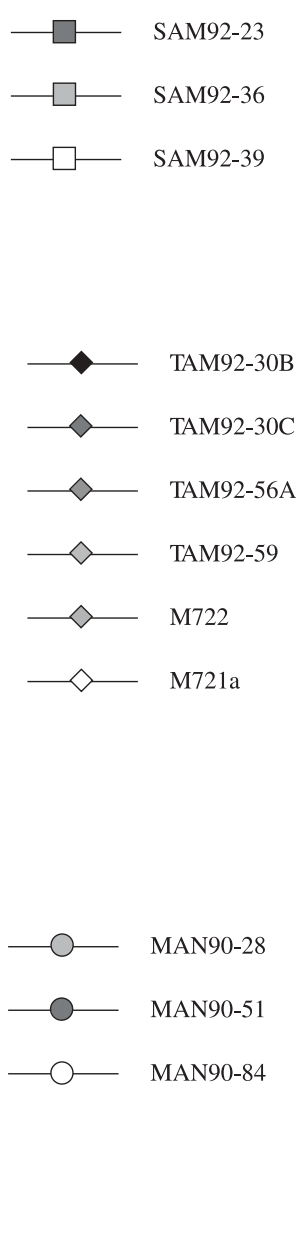

Fig. 6. Primitive mantle normalized diagrams (normalizing values from Sun \& McDonough 1989) of the samples of this study. The St Mary's Islands silicic rocks are plotted in all the diagrams as bold lines.

of Madagascar, and nowhere else in Madagascar, we use this information to fit India and Madagascar in a pre-drift position before the opening of the Mascarene basin in Late Cretaceous times (Fig. 7). Many palaeogeographical reconstructions of the India-Madagascar pre-drift relative positions are already available in the literature (Fig. 7). They are based on palaeomagnetism, backtracking the landmasses along the fracture zones of the Mascarene basin (Reeves \& de Wit 2000), correlating major Precambrian structures (in particular, the Archaean blocks of the western Dharwar craton cropping out in the Antongil Bay and Vatomandry areas; see de Wit 2003; Raval \& Veeraswamy 2003), mineralization (Dissanayake \& Chandrajith 1999), geometric fits of continental shelves (Yatheesh et al. 2006), and even palaeontological arguments (e.g. Bardhan et al. (2002) estimated a $<100 \mathrm{~km}$ separation between India and Madagascar during the Turonian, between $93.5 \pm 0.8$ and $89.3 \pm 1 \mathrm{Ma}$ ).

Our attempt to correlate rhyolitic units between eastern Madagascar and southwestern India is thus a complementary approach to that taken by other workers. The strong geochemical similarities between the St Mary's Islands rocks and the Vatomandry-Ilaka-Mananjary rhyolites, the distinct geochemical differences between the St Mary's Islands rocks and rhyolites elsewhere in eastern Madagascar, the absence of seaward-dipping reflectors along the very narrow continental shelf of eastern Madagascar (Storey et al. 1995), the difficulty of very viscous 

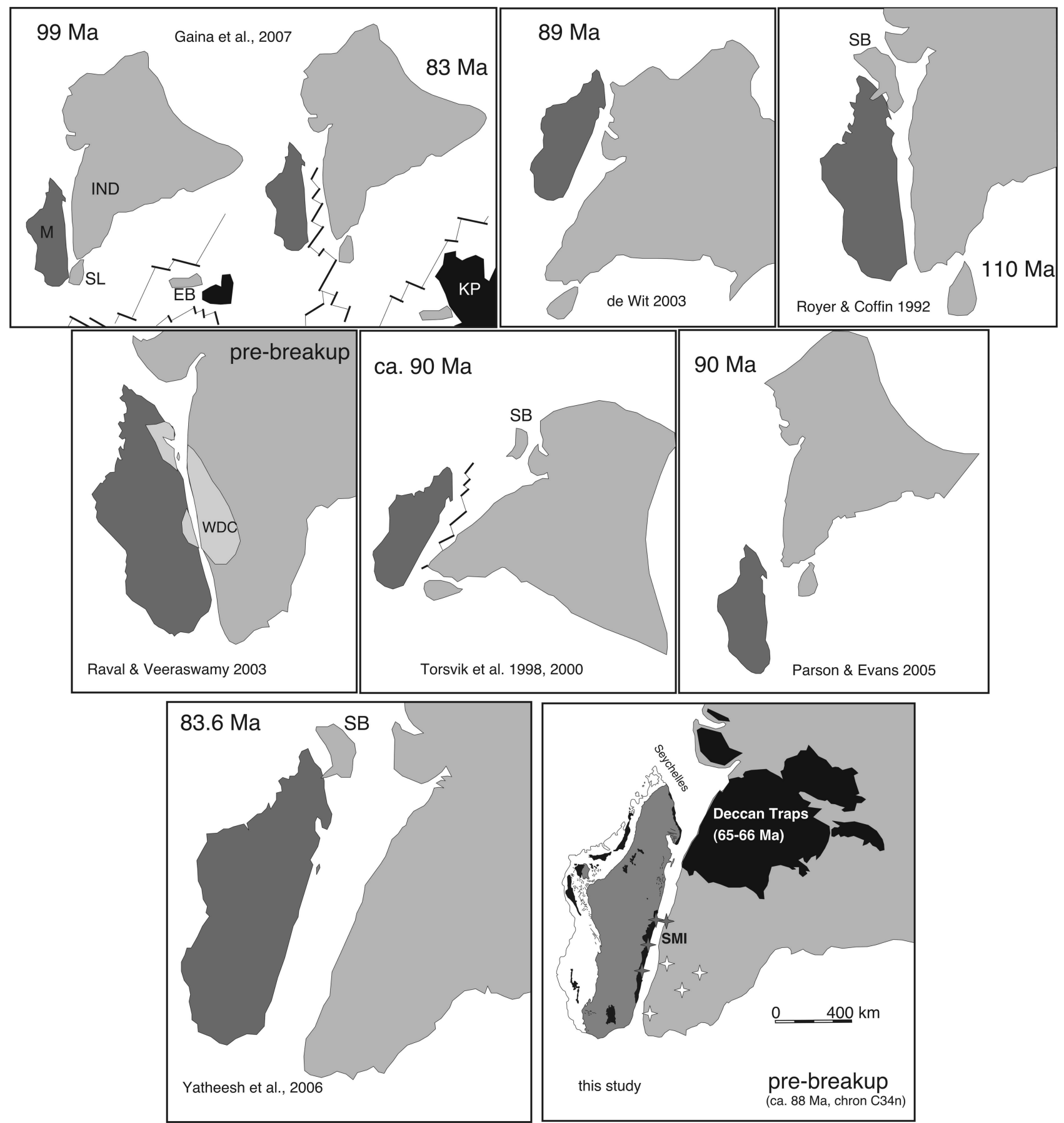

M, Madagascar; IND, India (Greater India); SL, Sri Lanka; SB, Seychelles Block; EB, Elan Bank;

KP, Kerguelen Plateau; WDC, western Dharwar craton with outliers in E Madagascar; SMI, St.Mary's Islands

Fig. 7. Sketch of various models of plate reconstructions between India and Madagascar. Our proposed fit is placed at $88 \mathrm{Ma}$, within the polarity chron C34n which marks the oldest known oceanic crust in the Mascarene basin (e.g. Bernard \& Munschy 2000, and references therein). The locations of the Cretaceous volcanic rocks of Madagascar (in black), and the later Deccan Traps are also shown. We also allowed space between northern Madagascar and western India for the position of the Seychelles microcontinent. The locations of contemporaneous basic intrusive rocks in southern India (Radhakhrishna et al. 1994, 1999; Kumar et al. 2001) are also shown (open stars). The dark grey stars mark the positions of the Mananjary-Vatomandry-Ilaka (Madagascar) and St Mary's Islands (India) outcrops. The continental shelves are not shown.

silicic flows travelling large distances, as well as the fact that some of our studied units (such as the Daryabahadurgarh granophyre and the Vatomandry rhyolite dykes) are shallow-level intrusions, mean that we are able to tightly constrain the south- central eastern coast of Madagascar and the southwestern coast of India in a Late Cretaceous pre-drift restoration at c. $88 \mathrm{Ma}$ (Fig. 7).

Our inferred palaeoposition of India and Madagascar is 
broadly consistent with reconstructions proposed by Katz \& Premoli (1979), Royer \& Coffin (1992), Storey et al. (1995), Dissanayake \& Chandrajith (1999), Yoshida et al. (1999), Raval \& Veeraswamy (2003), Yatheesh et al. (2006), Ali \& Aitchison (2008) and Eagles \& König (2008). Other proposed fits between Madagascar and India differ in placing India in a more northerly position (Torsvik et al. 1998, 2000; Parson \& Evans 2005) or Madagascar in a northerly position (Reeves \& de Wit 2000; de Wit 2003; Masters et al. 2006). These reconstructions do not all relate to the same age $(c .88 \mathrm{Ma})$, and the age is of course an important variable. Indeed, recent studies suggest that India moved northwards before Madagascar in the Early Cretaceous, in response to multiple openings of oceanic basins between India and Antarctica (see Coffin et al. 2002, and references therein), leading to strong sinistral strike-slip movements with Madagascar (Gaina et al. 2007). Later, Madagascar started to move northwards along the same strike-slip fault system (some faults were located in the Mozambique Basin; see Marks \& Tikku 2001). This fault system became the locus of drifting that led to the formation of the Mascarene Basin (Storey et al. 1995, and references therein). Although the relative movements of India and Madagascar may have been simpler than those described by Gaina et al. (2007) (see Eagles \& König 2008), caution should be used in correlating the position of the landmasses in the Late Cretaceous based on the fits of pre-Cretaceous (Precambrian) structures alone. If Madagascar and India moved in opposite senses during the Early Cretaceous (Gaina et al. 2007), the juxtaposed position of St Mary's Islands and the VatomandryIlaka-Mananjary rhyolites during the later part of the Cretaceous, realized in this study, constrains their Late Cretaceous positions much better than Precambrian geological features.

\section{Concluding remarks}

The rhyolites and dacites of the St Mary's Islands, southwestern India, have chemical and isotopic characteristics very different from those of typical anatectic melts of Precambrian continental crust, and are better explained as the products of fractional crystallization of tholeiitic basalt melts along with some crustal assimilation. These rhyolites and dacites are analogous to those cropping out extensively in eastern Madagascar. The somewhat anomalous but almost identical mineral chemical and whole-rock chemical and isotopic compositions of the St Mary's Islands rocks and the Vatomandry-Ilaka-Mananjary rhyolites definitely suggest closely similar magmatic evolution. They also suggest that these lavas, dykes and shallow subvolcanic intrusions must have occupied a common and relatively restricted area before the break-up of India and Madagascar at c. $88 \mathrm{Ma}$.

Finally, we note that some basic igneous rocks in southern India (mostly dolerite dykes) have a roughly similar age to the St Mary's Islands rhyolites (Radhakhrishna et al. 1994, 1999; Kumar et al. 2001). Some of these basic rocks may correlate with basic units in Madagascar (Storey et al. 1995), but more thorough sampling and petrographic, geochemical and age data on the Indian rocks than available at present are needed to evaluate these potential correlations.

We thank K. Pande for company and assistance in the field, and M. Marrazzo for her help with laboratory and microprobe work. M. Lustrino, R. de' Gennaro and M. Serracino are thanked for their help in obtaining microprobe data. S. Tommasini is particularly thanked for his help in the isotopic work in a period of troubles for the Firenze mass spectrometer. I. Rocco is also thanked for her help with analytical work at SOEST. A. Saunders was essential for the completion of this project, and is thanked for providing data, material and useful comments. This project was supported by Italian MIUR (PRIN grants 2004 to V.M.). D. Peate provided very useful input to improve an initial version of the manuscript, and discussions with various colleagues at the LIPS-IODP meeting in Coleraine (especially those with M. Coffin and R. Duncan) helped to tighten the contents of early versions. We acknowledge the detailed and constructive reviews of T. Barry and J. Marsh, the thorough reading and editorial comments of D. Peate, and the patience of A. Hills.

\section{References}

Ali, J.R. \& Aitchison, J.C. 2008. Gondwana to Asia: plate tectonics, paleogeography and the biological connectivity of the Indian sub-continent from the Middle Jurassic through latest Eocene (166-35 Ma). Earth-Science Reviews, 88, 145-166, doi:10.1016/j.earscirev.2008.01.007.

Avanzinelli, R., Boari, E., Conticelli, S., ET AL. 2005. High precision Sr, Nd and $\mathrm{Pb}$ isotopic analyses using the new generation thermal ionization mass spectrometer ThermoFinnigan Triton-Ti. Periodico di Mineralogia, 75, 147-166.

Bardhan, S., Gangopadhyay, T.K. \& Mandal, U. 2002. How far did India drift during the Late Cretaceous? Placenticeras kaffrarium Etheridge, 1904 (Ammonoidea) used as a measuring tape. Sedimentary Geology, 147, 193-217.

Bernard, A. \& Munschy, M. 2000. Le bassin des Mascareignes et le bassin de Laxmi (Océan Indien occidental) se sont-ils formés à l'axe d'un même centre d'expansion? Comptes Rendus de l'Académie des Sciences, 330, 777-783.

Besairie, H. 1964. Geological map of Madagascar, 1:1 000000 scale. Service Géologique de Madagascar, Tananarive.

Boynton, W.V. 1984. Cosmochemistry of the rare earth elements: meteorite studies. In: Henderson, P. (ed.) Rare Earth Element Geochemistry. Elsevier, Amsterdam, 63-114.

Chand, S. \& Subrahmanyam, C. 2003. Rifting between India and Madagascarmechanism and isostasy. Earth and Planetary Science Letters, 210, 317-332.

Coffin, M.F., Pringle, M.S., Duncan, R.A., Gladczenko, T.P., Storey, M., MülleR, R.D. \& GahaGan, L.A. 2002. Kerguelen hotspot magma output since 130 Ma. Journal of Petrology, 43, 1121-1139.

Devey, C.W. \& Stephens, W.E. 1991. Tholeiitic dykes in the Seychelles and the original spatial extent of the Deccan. Journal of the Geological Society, London, 148, 979-983.

Devey, C.W. \& Stephens, W.E. 1992. Deccan-related magmatism west of the Seychelles-India rift. In: Storey, B.C., Alabaster, T. \& Pankhurst, R.J. (eds) Magmatism and the Causes of Continental Break-up. Geological Society, London, Special Publications, 68, 271-291.

DE WIT, M.J. 2003. Madagascar: heads it's a continent, tails it's an island. Annual Review of Earth and Planetary Sciences, 31, 213-248.

Dissanayake, C.B. \& Chandrajith, R. 1999. Sri Lanka-Madagascar Gondwana linkage: evidence for a Pan-African mineral belt. Journal of Geology, 107, $223-235$.

EAGLes, G. \& KöNIG, M. 2008. A model of plate kinematics in Gondwana breakup. Geophysical Journal International, 173, 703-717, doi:10.1111/j.1365246X.2008.03753.x.

Encarnación, J., Fleming, T.H., Elliot, D.H. \& Eales, H.V. 1996. Synchronous emplacement of Ferrar and Karoo dolerites and the early breakup of Gondwana. Geology, 24, 535-538.

Gaina, C., Müller, R.D., Brown, B., Ishihara, T. \& Ivanov, S. 2007. Breakup and early seafloor spreading between India and Antarctica. Geophysical Journal International, 170, 151-169.

Geological Survey of Madagascar 1959. Sheets Mahatsara, T48, and Vatoman$d r y, U 48,1: 100000$ scale. Geological Survey of Madagascar, Antananarivo.

Gladczenko, T.P., Skogseid, J. \& Eldholm, O. 1998. Namibia volcanic margin. Marine Geophysical Researches, 20, 313-341.

Hegde, V.S. \& Gosavi, D.K. 2007. Plume related (?) acid volcanic activity in St. Mary's Islands, South Kanara District, Karnataka. Journal of the Geological Society of India, 70, 43-52.

Hergt, J.M., Peate, D.W. \& Hawkesworth, C.J. 1991. The petrogenesis of Mesozoic Gondwana low-Ti flood basalts. Earth and Planetary Science Letters, 105, 134-148.

Katz, M.B. \& Premoli, C. 1979. India and Madagascar in Gondwanaland based on matching Precambrian lineaments. Nature, 279, 312-315.

Kumar, A., Pande, K., Venkatesan, T.R. \& Bhaskar RaO, Y.J. 2001. The Karnataka Late Cretaceous dikes as products of the Marion hot spot at the Madagascar-India breakup event: evidence from ${ }^{40} \mathrm{Ar} /{ }^{39} \mathrm{Ar}$ geochronology and geochemistry. Geophysical Research Letters, 228, 2715-2718.

Lacroix, A. 1923. Minéralogie du Madagascar, Vol. 3. Augustin Challamel, Paris.

Larsen, L.M., WaAgstein, R., Pedersen, A.K. \& Storey, M. 1999. TransAtlantic correlation of the Palaeogene volcanic successions in the Faeroe Islands and East Greenland. Journal of the Geological Society, London, 156, $1081-1095$. 
Le Bas, M.J., Le Maitre, R.W., Streckeisen, A. \& Zanettin, P. 1986. A chemical classification of volcanic rocks based on the total alkali-silica diagram. Journal of Petrology, 27, 745-750.

LEPAGE, L.D. 2003. ILMAT: an Excel worksheet for ilmenite-magnetite geothermometry and geobarometry. Computers and Geosciences, 29, 673-678.

Lindsley, D.H. 1983. Pyroxene thermometry. American Mineralogist, 68, $477-$ 493.

Mahoney, J.J., Nicollet, C. \& Dupuy, C. 1991. Madagascar basalts: tracking oceanic and continental sources. Earth and Planetary Science Letters, 104, $350-363$.

Mahoney, J.J., Saunders, A.D., Storey, M. \& Randriamanantenasoa, A. 2008. Geochemistry of the Volcan de l'Androy basalt-rhyolite complex, Madagascar Cretaceous igneous province. Journal of Petrology, 49, 10691096, doi:10.1093/petrology/egn018.

Marks, K.M. \& TIKKU, A.A. 2001. Cretaceous reconstructions of East Antarctica, Africa and Madagascar. Earth and Planetary Science Letters, 186, 479-495.

Marsh, J.S., Ewart, A., Milner, S.C., Duncan, A.R. \& Miller, R.McG. 2001. The Etendeka igneous province: magma types and their stratigraphic distribution with implications for the evolution of the Paraná-Etendeka flood basalt province. Bulletin of Volcanology, 62, 464-486

Marzoli, A., Renne, P.R., Piccirillo, E.M., Ernesto, M., Bellieni, G. \& De Min, A. 1999. Extensive 200-million-year-old continental flood basalts of the Central Atlantic magmatic province. Science, 284, 616-618.

Masters, J.C., DE Wit, M.J. \& Asher, R.J. 2006. Reconciling the origins of Africa, India and Madagascar with vertebrate dispersal scenarios. Folia Primatologica, 77, 399-418.

Melluso, L., Morra, V., Brotzu, P., Razafiniparany, A., Ratrimo, V. \& Razafimahatratra, D. 1997. Geochemistry and Sr-isotopic composition of the late Cretaceous flood basalt sequence of northern Madagascar: petrogenetic and geodynamic implications. Journal of African Earth Sciences, 34, 371-390.

Melluso, L., Morra, V., Brotzu, P. \& Mahoney, J.J. 2001. The Cretaceous igneous province of central-western Madagascar: evidence for heterogeneous mantle sources, crystal fractionation and crustal contamination. Journal of Petrology, 42, 1249-1278.

Melluso, L., Morra, V., Brotzu, P., D’Antonio, M. \& Bennio, L. 2002. Petrogenesis of the Late Cretaceous tholeiitic magmatism in the passive margins of northeastern Madagascar. In: Menzies, M.A., Ebinger, C.J. \& BAKer, J. (eds) Volcanic Rifted Margins. Geological Society of America, Special Papers, 362, 83-98.

Melluso, L., Morra, V., Brotzu, P., Franciosi, L., Petteruti Liebercknecht, A.M. \& Bennio, L. 2003. Geochemical provinciality in the Cretaceous magmatism of northern Madagascar, and mantle source implications. Journal of the Geological Society, London, 160, 477-488.

Melluso, L., Morra, V., Brotzu, P., et AL. 2005. Geochronology and petrogenesis of the Cretaceous Antampombato-Ambatovy complex and associated dyke swarm, Madagascar. Journal of Petrology, 46, 1963-1996.

Melluso, L., Morra, V. \& Fedele, L. 2006. An overview of phase chemistry and magmatic evolution in the Cretaceous flood basalt province of northern Madagascar. Periodico di Mineralogia, 75, 174-188.

Milner, S.C., Duncan, A.R., Whittingham, A.M. \& Ewart, A. 1995. TransAtlantic correlations of eruptive sequences and individual silicic units within the Paraná-Etendeka igneous province. Journal of Volcanology and Geothermal Research, 69, 137-157.

NAGAnNA, C. 1966. Petrology of the rocks of St. Mary's islands, near Malpe, south Kanara District, Mysore state. Journal of the Geological Society of India, 7, $110-117$.

Nicollet, C. 1984. Le volcanisme dans le Sud-Ouest de Madagascar. Journal of African Earth Sciences, 2, 383-388.

Pande, K., Sheth, H.C. \& Bhutani, R. 2001. ${ }^{40} \mathrm{Ar} /{ }^{39} \mathrm{Ar}$ age of the St. Mary's Islands volcanics, southern India: record of India-Madagascar break-up on the Indian subcontinent. Earth and Planetary Science Letters, 193, 39-46.

PARSON, L.M. \& Evans, A.J. 2005. Seafloor topography and tectonic elements of the Western Indian Ocean. Philosophical Transactions of the Royal Society of London, Series A, 363, 15-24.

Peate, D.W. 1997. The Paraná-Etendeka Province. In: Mahoney, J.J. \& Coffin, M.F. (eds) Large Igneous Provinces: Continental, Oceanic and Planetary Flood Volcanism. American Geophysical Union, Geophysical Monograph, 100, 217-245

Peate, D.W., Hawkesworth, C.J., Mantovani, M.S.M., Rogers, N.W. \& Turner, S.P. 1999. Petrogenesis and stratigraphy of the high-Ti/Y Urubici magma type in the Paraná flood basalt province and implications for the nature of 'Dupal-type' mantle in the South Atlantic region. Journal of Petrology, 40, 451-473.

Radhakhrishna, T., Dallmeyer, R.D. \& Joseph, M. 1994. Palaeomagnetism and
${ }^{36} \mathrm{Ar} /{ }^{40} \mathrm{Ar}$ vs. ${ }^{39} \mathrm{Ar} /{ }^{40} \mathrm{Ar}$ isotope correlation ages of dyke swarms in central Kerala, India: Tectonic implications. Earth and Planetary Science Letters, 121, 213-226.

Radhakhrishna, T., Maluski, H., Mitchell, J.G. \& Joseph, M. 1999. ${ }^{40} \mathrm{Ar} /{ }^{39} \mathrm{Ar}$ and $\mathrm{K} / \mathrm{Ar}$ geochronology of the dykes from the south Indian granulite terrain. Tectonophysics, 304, 109-129.

RAVAL, U. \& VeERAswamy, K. 2003. India-Madagascar separation: breakup along a pre-existing mobile belt and chipping of the craton. Gondwana Research, 6 , $467-485$.

ReEves, C. \& DE WIT, M.J. 2000. Making ends meet in Gondwana: retracting the transforms of the Indian Ocean and reconnecting continental shear zones. Terra Nova, 12, 272-280

Renne, P.R., Swisher, C.C., III, Deino, A.L., Karner, D.B., Owens, T.L. \& DePAOLO, D.J. 1998. Intercalibration of standards, absolute ages and uncertainties in ${ }^{40} \mathrm{Ar} /{ }^{39} \mathrm{Ar}$ dating. Chemical Geology, 145, 117-152.

Riley, T.R., Curtis, M.L., Leat, P.T., Watkeys, M.K., Duncan, R.A., Millar, I.L. \& Owens, W.H. 2006. Overlap of Karoo and Ferrar magma types in KwaZulu-Natal, South Africa. Journal of Petrology, 47, 541-566.

RoYer, J.-Y. \& COFFIN, M.F. 1992. Jurassic to Eocene plate tectonic reconstructions in the Kerguelen plateau region. In: WISE, S.W., JR, SCHLICH, R., ET AL. (eds.) Proceedings of the Ocean Drilling Program, Scientific Results, 120. Ocean Drilling Program, College Station, TX, 917-928.

Saunders, A.D., Fitton, J.G., Kerr, A.C., Norry, M.J. \& Kent, R.W. 1997. The North Atlantic Igneous Province. In: Mahoney, J.J. \& Coffin, M.F. (eds) Large Igneous Provinces: Continental, Oceanic and Planetary Flood Volcanism. American Geophysical Union, Geophysical Monograph, 100, 45-93.

Sheth, H.C. \& Melluso, L. 2008. The Mount Pavagadh volcanic suite, Deccan Traps: geochemical stratigraphy and magmatic evolution. Journal of Asian Earth Sciences, 32, 5-21, doi:10.1016/j.jseaes.2007.10.001.

Storey, M., Mahoney, J.J., Saunders, A.D., Duncan, R.A., Kelley, S.P. \& CofFin, M.F. 1995. Timing of hot spot-related volcanism and the breakup of Madagascar and India. Science, 267, 852-855.

Storey, M., Mahoney, J.J. \& Saunders, A.D. 1997. Cretaceous basalts in Madagascar and the transition between plume and continental lithosphere mantle sources. In: MAHoney, J.J. \& Coffin, M.F. (eds) Large Igneous Provinces: Continental, Oceanic and Planetary Flood Volcanism. American Geophysical Union, Geophysical Monograph, 100, 95-122.

Storey, M., Duncan, R.A. \& Swisher, C.C., III 2007. Paleocene-Eocene thermal maximum and the opening of the Northeast Atlantic. Science, 316, 587-589.

Subbarao, K.V., Valsangkar, A.B. \& Viswanathan, S. 1993. Mineralogy of the acid volcanics of St. Mary's Islands. Proceedings of the National Academy of Sciences, India, 63, 97-117.

Sun, S.-S. \& McDonough, W.F. 1989. Chemical and isotopic systematics of oceanic basalts: implications for mantle composition and processes. In: SAunders, A.D. \& Norry, M.J. (eds) Magmatism in the Ocean Basins. Geological Society, London, Special Publications, 42, 313-345.

Torsvik, T.H., Tucker, R.D., Ashwal, L.D., Eide, E.A., Rakotosolofo, N.A. \& DE WIT, M.J. 1998. Late Cretaceous magmatism of Madagascar: paleomagnetic evidence for a stationary hotspot. Earth and Planetary Science Letters, 164, 221-232.

Torsvik, T.H., Tucker, R.D., Ashwal, L.D., Carter, L.M., Jamtveit, B., Vidyadharan, K.T. \& Venkataramana, P. 2000. Late Cretaceous IndiaMadagascar fit and timing of break-up related magmatism. Terra Nova, 12, $220-224$.

Ukstins Peate, I., Baker, J.A., Kent, A.J.R., Al-Kadasi, M., Al-Subbary, A., Ayalew, D. \& Menzies, M.A. 2003. Correlation of Indian Ocean tephra to individual Oligocene silicic eruptions from Afro-Arabian flood volcanism. Earth and Planetary Science Letters, 211, 311-327.

Ukstins Peate, I., BaKer, J.A., Al-Kadasi, M., ET AL. 2005. Volcanic stratigraphy of large-volume silicic pyroclastic eruptions during Oligocene Afro-Arabian flood volcanism in Yemen. Bulletin of Volcanology, 68, 135-156.

Valsangkar, A.B. 1980. Petrology and paleomagnetism of volcanic rocks of the St. Mary's Islands. PhD thesis, Indian Institute of Technology, Mumbai.

ValsangKar, A.B., Radhakrishnamurthy, C., Subbarao, K.V. \& Beckinsale, R.D. 1981. Palaeomagnetism and potassium-argon age studies of acid igneous rocks from the St. Mary Islands. In: Subbarao, K.V. \& SukHeswaLA, R.N. (eds) Deccan Volcanism. Memoirs, Geological Society of India, 3, $265-276$.

Yatheesh, V., Bhattacharya, G.C. \& Mahender, K. 2006. The terrace-like feature in the mid-continental slope region off Trivandrum and a plausible model for India-Madagascar juxtaposition in immediate pre-drift scenario. Gondwana Research, 10, 179-185.

Yoshida, M., Rajesh, H.M. \& SAntosh, M. 1999. Juxtaposition of India and Madagascar: a perspective. Gondwana Research, 3, 449-462. 